\title{
THE EFFECT OF ANEMIA ON THE ALVEOLAR-CAPILLARY EXCHANGE OF CARBON MONOXIDE IN MAN *
}

\author{
By J. RANKIN, $†$ R. S. MCNEILL $\ddagger$ AND R. E. FORSTER § \\ (From the Department of Physiology, Graduate School of Medicine, University of Pennsylvania, \\ Philadelphia, $P a$.)
}

(Submitted for publication October 31, 1960; accepted March 30, 1961)

Previous work has demonstrated that the exchange of $\mathrm{CO}$ between alveolar gas and pulmonary capillary blood is at least partially limited by the rate at which it can combine reversibly with intracellular hemoglobin. The relative importance of the rate of gas diffusion across the pulmonary membrane and the rate of gas uptake by the red cells in determining the over-all rate of alveolar capillary gas exchange has been expressed by the relation (1):

$$
1 / \mathrm{D}_{\mathrm{L}}=1 / \mathrm{D}_{\mathbf{M}}+1 / \theta \mathrm{V}_{\mathbf{c}}
$$

In this equation $D_{L}$ is the over-all diffusing capacity of the lungs and $D_{M}$ is that of the pulmonary membrane alone, both given in milliliters of gas per minute per millimeter $\mathrm{Hg} ; \mathrm{V}_{\mathrm{c}}$ is the average volume of blood in the pulmonary capillary bed and $\theta$ is the rate at which $1 \mathrm{ml}$ of this blood combines with $\mathrm{CO}$ in milliliters of gas reacting per minute per millimeter $\mathrm{CO}$ tension; $\theta$ equals the product of the number of grams of hemoglobin per milliliter of blood and the gas uptake rate per gram of hemoglobin. By analogy, the movement of gas between the alveoli and the red cell interior may be compared with the flow of electricity through two resistances in series where $1 / D_{L}$ is the total resistance, $1 / \mathrm{D}_{\mathbf{M}}$ is that of the membrane alone and $1 / \theta \mathrm{V}_{\mathrm{c}}$ is that of the average total mass of red cells in the pulmonary capillary bed at any instant ; $\theta$ decreases as capillary $\mathrm{O}_{2}$ tension rises, because $\mathrm{O}_{2}$ competes with $\mathrm{CO}$ for intracellular hemoglobin, in effect lowering the chemical reaction rate. By measuring $D_{\mathrm{L}}$ at two or more dif-

* This work was supported by a grant from the Life Insurance Medical Research Fund. It was presented as an abstract in J. clin. Invest. 1957, 36, 922.

† Present address: Department of Medicine, Univ. of Wisconsin, Madison, Wis.

$\ddagger$ Present address: Department of Pharmacology and Therapeutics, Univ. of St. Andrew's Medical School, Dundee, Scotland.

$\S$ Lowell M. Palmer Senior Fellow. ferent capillary $\mathrm{O}_{2}$ tensions for which corresponding values of $\theta$ are known, the data can be obtained for the solution of Equation 1 for both $D_{\mathbf{M}}$ and $\mathrm{V}_{\mathrm{c}}$.

When the concentration of red cells in the pulmonary capillary blood is decreased, without any remarkable changes in the gas uptake rate of the individual cell, $\theta$ also decreases and the formula predicts that $D_{L}$ will decrease as well. In order to determine the physiological effects of anemia on gas exchange and also to confirm the validity of Equation 1, we have measured $D_{L}, D_{M}$, and $V_{c}$ in five patients with severe iron-deficiency anemia without significant pulmonary disease, both before and after therapy.

\section{METHODS AND SUBJECTS}

The pulmonary diffusing capacity was determined by a modification of the Krogh breath-holding technique (2), in which the seated resting subject makes a maximal inspiration from residual volume of a gas mixture containing approximately 0.3 per cent $\mathrm{CO}, 10$ per cent $\mathrm{He}$, and the remainder $\mathrm{O}_{2}$ and $\mathrm{N}_{2}$. An alveolar sample is obtained from the expirate after a 10 -second period of breath-holding. The expired alveolar sample was dried and analyzed on an infrared analyzer for $\mathrm{CO}$, and on a continuously-sampling mass spectrometer for $\mathrm{He}, \mathrm{O}_{2}$ and $\mathrm{CO}_{2}$. Appropriate corrections were applied for the slight sensitivity of the instrument to $\mathrm{CO}_{2} ; 4$ per cent $\mathrm{CO}_{2}$ gave a response equivalent to 0.001 per cent $\mathrm{CO}$.

Measurements of $D_{L}$ were repeated at several alveolar oxygen tensions from about 100 to approximately 600 $\mathrm{mm} \mathrm{Hg}$. The alveolar oxygen tension during the measurement of $\mathrm{D}_{\mathrm{L}}$ was varied $a$ ) by having the subject inspire gas mixtures containing different concentrations of oxygen during the actual measurement of $\mathrm{D}_{\mathrm{L}}$; and $b$ ) by having the subject breathe 99.5 per cent oxygen or air for several minutes prior to the measurement.

Knowing $D_{L}$ for several different oxygen tensions, Equation 1 was solved graphically for $\mathrm{D}_{\mathbf{M}}$ and $\mathrm{V}_{\mathbf{c}}(3) ; \theta$ was obtained from the data of Roughton and Forster (1) who use a value of 2.5 for the ratio of the permeability of the red cell membrane to that of the interior of the cell; $\theta$ is proportional to the concentration of hemoglobin (or of normal red cells) in the blood. The values of $\theta$ 
were derived for an assumed blood hemoglobin concentration of $14.9 \mathrm{~g}$ per $100 \mathrm{ml}$ (equivalent to an $\mathrm{O}_{2}$ or $\mathrm{CO}$ combining capacity of $20 \mathrm{ml}$ per $100 \mathrm{ml}$ ). When the pulmonary capillary hemoglobin concentration does not equal this value, $\theta$ may be obtained by direct proportion.

The measurements of $D_{L}$ were corrected for the presence of significant amounts of $\mathrm{COHb}$ in the mixed venous blood by subtracting the equilibrated $\mathrm{CO}$ tension owing to this compound. After washing out most of the nitrogen in the lungs by breathing approximately 100 per cent $\mathrm{O}_{2}$ beforehand, which resulted in an alveolar $\mathrm{O}_{2}$ tension of about $600 \mathrm{~mm} \mathrm{Hg}$, the equilibrated $\mathrm{CO}$ tension was obtained by breath-holding for 1.5 minutes. Estimates of equilibrated blood $\mathrm{CO}$ tension were obtained in this manner before and after a group of measurements of $D_{L}$, and the correct value for the individual measurement obtained by interpolation and proportioned to the appropriate $\mathrm{O}_{2}$ tension (4). The calculations are not precise for alveolar $\mathrm{O}_{2}$ tensions of much less than $200 \mathrm{~mm} \mathrm{Hg}$, but are adequate for the present purposes.

Residual volume was measured by the open circuit nitrogen washout method of Darling, Cournand and Richards (5). Maximal expiratory and inspiratory flow rates were calculated by the method of Cander and Comroe (6). The evenness of distribution of inspired gas was measured in four of the five patients by the singlebreath $\mathrm{O}_{2}$ method (7).

We desired subjects for this investigation who had physiologically normal lungs and cardiovascular systems, and who could be studied $a$ ) at a time when their blood hemoglobin was very low, and later $b$ ) when it had been raised by therapy. The most common condition in which these circumstances prevail is a previously undiagnosed anemia resulting from acute or chronic blood loss, immediately prior to and after blood transfusion. We were able to study only five patients fulfilling these criteria over a period of more than a year. Their vital statistics, pulmonary function tests and primary diagnoses are given in Table I. Pulmonary function tests were repeated only in Patient 5, whose average results are given. None of these patients had any history, physical signs, or indications by $\mathrm{X}$-ray examination of respiratory disease. Since it is desirable to treat any patient with a markedly low hematocrit as soon as possible, it was difficult to obtain complete pulmonary function studies (particularly arterial blood analyses) on each patient while he was in his most anemic state, but this was largely accomplished, save in Patient 1.

$\mathrm{He}$ had a large hiatus hernia with gastrointestinal bleeding and this was considered the major cause of his anemia, although some of the blood findings were not wholly explicable on this basis. Owing to his condition, it was necessary to perform all studies while he was supine.

Patient 2 had large myofibromata of the uterus with considerable vaginal bleeding She also gave a history suggesting heart disease some 20 years earlier. The day before the first measurements of $\mathrm{D}_{\mathrm{L}}$, the patient devel-

TABLE I

Vital statistics and results of pulmonary function tests *

\begin{tabular}{|c|c|c|c|c|c|c|c|c|c|c|c|}
\hline Patient diagnosis & Age & Sex & BSA & $\mathrm{VC}$ & RV & TLC & $\begin{array}{l}\text { RV/ } \\
\text { TLC }\end{array}$ & MIFR & MEFR & MBC & $\underset{\substack{\mathrm{N}_{2} \\
\text { formity }}}{\mathrm{N}_{\mathrm{i}}}$ \\
\hline$\stackrel{1}{\text { Hiatus hernia }}$ & 44 & $\sigma^{7}$ & $\begin{array}{c}m^{2} \\
1.80\end{array}$ & $\begin{array}{c}m l \\
4,650 \\
(3,850)\end{array}$ & $\begin{array}{c}m l \\
3,450 \\
(1,180)\end{array}$ & $\begin{array}{c}m l \\
8,100 \\
(5,030)\end{array}$ & $\begin{array}{l}\% \\
42\end{array}$ & $\begin{array}{c}L / \min \\
270\end{array}$ & $\begin{array}{c}L / \min \\
590\end{array}$ & $L / \min$ & $\begin{array}{l}\% \mathrm{~N}_{2} \\
1.7\end{array}$ \\
\hline$\stackrel{2}{2}$ Uterine fibromata & 38 & 우 & 1.56 & $\begin{array}{c}2,730 \\
(2,890)\end{array}$ & $\begin{array}{c}1,690 \\
(880)\end{array}$ & $\begin{array}{c}4,420 \\
(3,700)\end{array}$ & 38 & 226 & 259 & & 1.2 \\
\hline $\begin{array}{l}3 \\
\text { Uterine fibromata }\end{array}$ & 40. & q & 1.78 & $\begin{array}{c}3,570 \\
(2,800)\end{array}$ & $\begin{array}{c}1,828 \\
(855)\end{array}$ & $\begin{array}{c}5,398 \\
(3,655)\end{array}$ & 34 & 280 & 253 & 84 & $0.5 \dagger$ \\
\hline$\stackrel{4}{\underset{\text { Carcinoma of }}{\text { cervix }}}$ & 52 & 웅 & 1.51 & $\begin{array}{c}2,760 \\
(2,630)\end{array}$ & $\begin{array}{r}2,365 \\
(800)\end{array}$ & $\begin{array}{c}5,365 \\
(3,430)\end{array}$ & 44 & 270 & 485 & & 0.7 \\
\hline $\begin{array}{c}5 \\
\text { Carcinoma of } \\
\text { cervix }\end{array}$ & 53 & q & 1.70 & $\begin{array}{l}2,380 \\
(2,670)\end{array}$ & $\begin{array}{c}1,792 \\
(810)\end{array}$ & $\begin{array}{c}4,172 \\
(3,480)\end{array}$ & 43 & 230 & 260 & 80 & 0 \\
\hline
\end{tabular}

* Diagnosis refers to the condition producing the anemia via chronic blood loss. VC is vital capacity, RV residual volume, TLC total lung capacity (all in ml BTPS). Predicted normal values (8) are given in the parentheses. MIFR and MEFR are maximal inspiratory and expiratory flow rates in liters BTPS/min. The normal values are between 200 and $600 \mathrm{~L} / \mathrm{min}$. $\mathrm{MBC}$ is the maximal voluntary ventilation in liters BTPS $/ \mathrm{min}$. The normal values are given in parentheses (9). $\quad \mathrm{N}_{2}$ uniformity [single breath $\mathrm{N}_{2}$ test (7)] is the change in expired alveolar $\mathrm{N}_{2} \%$ between 750 and $1,250 \mathrm{ml}$ of expirate. The normal value is $2 \%$ or less. The first study on Patient 1 had to be done supine. Pulmonary function studies were repeated about 1 week after treatment in Patient 5; average values are given. There were no significant changes.

$\dagger$ This figure is the percentage of $\mathrm{N}_{2}$ in the expired alveolar gas after breathing $\mathrm{O}_{2}$ for 7 minutes. A normal value would be $<2.5 \%$ (5). 
TABLE II

Results of measurements of diffusing capacity of the lung in five patients with anemia *

\begin{tabular}{|c|c|c|c|c|c|c|c|c|c|}
\hline \multicolumn{3}{|c|}{ Patient } & \multirow{2}{*}{$\frac{\mathrm{Hb}}{\mathrm{g} / 100 \mathrm{ml}}$} & \multirow{2}{*}{$\frac{\mathrm{D}_{\mathrm{L}}}{\mathrm{ml}_{\mathrm{m} / \min }^{\mathrm{min}}}$} & \multirow{3}{*}{$\begin{array}{c}\mathrm{D}_{\mathrm{L}_{120}} \\
\mathrm{ml} / \mathrm{min} \\
\times \mathrm{mm}^{\mathrm{min}} \mathrm{Hg} \\
25 \\
(27.2)\end{array}$} & \multirow{3}{*}{ 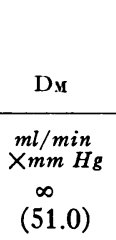 } & \multirow{3}{*}{$\begin{array}{c}\mathrm{V}_{0} \\
m l \\
66.7 \\
(82.0)\end{array}$} & \multirow{3}{*}{$\begin{array}{c}\begin{array}{c}\text { Cell re- } \\
\text { sistance/ } \\
\text { membrane } \\
\text { resistance }\end{array} \\
\%\end{array}$} & \multirow{3}{*}{$\begin{array}{c}\theta \mathrm{V}_{0} \\
19 \\
(57.4)\end{array}$} \\
\hline & & & & & & & & & \\
\hline 1 & $\begin{array}{l}1 / 20 / 56 \dagger \\
1 / 24 / 56\end{array}$ & Transfused & 6.2 & & & & & & \\
\hline & $\begin{array}{l}2 / 5 / 56 \\
2 / 8 / 56\end{array}$ & & $\begin{array}{l}11.0 \\
11.5\end{array}$ & $\begin{array}{l}23.3 \\
26.4\end{array}$ & $\begin{array}{l}27.8 \\
26.7\end{array}$ & $\begin{array}{l}55.6 \\
44.3\end{array}$ & $\begin{array}{l}105.0 \\
109.0\end{array}$ & $\begin{array}{r}100 \\
70\end{array}$ & $\begin{array}{l}53 \\
58.5\end{array}$ \\
\hline \multirow[t]{3}{*}{2} & \multirow{3}{*}{\multicolumn{2}{|c|}{$\begin{array}{ll}3 / 20 / 56 & \text { Transfused } 60 \mathrm{ml} \\
3 / 21 / 56 & \\
3 / 26 / 56 & \text { Hysterectomy; } \\
4 / 2 / 56 & \text { transfused }\end{array}$}} & ; stopped & on reaction & & & & & \\
\hline & & & 7.5 & 14.0 & $\begin{array}{c}13.7 \\
(22.6)\end{array}$ & $\begin{array}{c}19.6 \\
(42.3)\end{array}$ & $\begin{array}{c}91 \\
(68.0)\end{array}$ & 43 & $\begin{array}{c}31.7 \\
(47.5)\end{array}$ \\
\hline & & & 10.7 & 16.3 & 15.4 & 27.8 & 79 & 81 & 80 \\
\hline \multirow[t]{2}{*}{3} & $\begin{array}{l}4 / 9 / 56 \\
4 / 10 / 56 \\
\text { to }\end{array}$ & $\begin{array}{l}\text { Transfused } \\
\text { total } 2\end{array}$ & 5.9 & 13.3 & $\begin{array}{c}13.2 \\
(26.8)\end{array}$ & $\begin{array}{c}33.2 \\
(50.1)\end{array}$ & $\begin{array}{c}80.5 \\
(81.0)\end{array}$ & 150 & $\begin{array}{l}45 \\
(56.7)\end{array}$ \\
\hline & $\begin{array}{l}4 / 16 / 56 \\
4 / 25 / 56\end{array}$ & L & 11.4 & 20.5 & 20.5 & 37.0 & 87.0 & 127 & 94 \\
\hline \multirow[t]{2}{*}{4} & $6 / 20 / 56$ & tonger & 4.6 & 6.6 & 6.6 & 8.1 & 62.5 & 23 & 27 \\
\hline & $6 / 25 / 56$ & anstuseca & 12.4 & 17.6 & 17.4 & 28.6 & 65.0 & 64 & 76 \\
\hline \multirow[t]{2}{*}{5} & $\begin{array}{l}6 / 30 / 56 \\
7 / 2-3 / 56\end{array}$ & Transfused & 5.9 & 12.2 & $\begin{array}{c}10.8 \\
(25.3)\end{array}$ & $\begin{array}{c}45.5 \\
(47.4)\end{array}$ & $\begin{array}{c}54.3 \\
(76.5)\end{array}$ & 320 & $\begin{array}{l}30 \\
(53.5)\end{array}$ \\
\hline & $7 / 3 / 56$ & & 9.2 & 16.5 & 15.7 & 50.0 & 62.5 & 220 & 54 \\
\hline
\end{tabular}

* $\mathrm{Hb}$ is blood hemoglobin concentration. $\mathrm{D}_{\mathrm{L}}$ is diffusing capacity of the lung as measured using an inspired gas mixture containing about $21 \% \mathrm{O}_{2}$. $\mathrm{D}_{\mathrm{L}_{120}}$, value of $\mathrm{D}_{\mathrm{L}}$ corrected to alveolar $\mathrm{O}_{2}$ tension of $120 \mathrm{~mm} \mathrm{Hg}$ according to Equation 1. $D_{\mathbf{M}}$, diffusing capacity of pulmonary membrane. $V_{c}$, volume of blood in pulmonary capillary bed, assuming that hematocrit of this blood equals that in the major vessels. Figures in parentheses are normal predicted values. $D_{L}$ is predicted according to patient's surface area (2). $\mathrm{V}_{\mathrm{c}}=3.03 \times \mathrm{D}_{\mathrm{L}_{120}} ; \mathrm{D}_{\mathrm{M}}=1.87 \times \mathrm{D}_{\mathrm{L}_{120}}$; and $\theta(2)$ at $\mathrm{Po}_{2}=120 \mathrm{~mm}$ $\mathrm{Hg}=0.7 \mathrm{ml} / \mathrm{min} / \mathrm{ml}$ normal blood $/ \mathrm{mm} \mathrm{Hg} \mathrm{CO}$ partial pressure (3). Cell resistance/membrane resistance is ratio of resistance to diffusion of $\mathrm{CO}$ within the blood as compared with that across the pulmonary membrane. $\theta \mathrm{V}_{\mathrm{c}}=\mathrm{ml} \mathrm{CO}$ entering average total red cells in pulmonary capillary bed in 1 second for a pressure gradient of $1 \mathrm{~mm} \mathrm{Hg}$.

$\dagger$ This study was performed with the patient supine; in subsequent studies he was sitting.

oped an urticarial reaction, fever, and partial heart block after receiving about $60 \mathrm{ml}$ of a transfusion. Several days after her transfusion reaction she had a hysterectomy and oophorectomy with blood replacement. The measurements of $\mathrm{D}_{\mathrm{L}}$ were repeated after the operation.

Patient 3 had large myofibromata of the uterus with severe vaginal bleeding. She was studied before and after blood transfusion in preparation for subsequent hysterectomy.

Patient 4 had carcinoma of the cervix with vaginal bleeding producing a severe anemia. She was studied before and after blood replacement.

Patient 5 had carcinoma of the cervix with extension into the pelvis and her only symptom was severe vaginal bleeding.

\section{RESULTS AND DISCUSSION}

The results of the tests given in Table I show that the pulmonary function of these patients was essentially normal, although they were extremely weak and found it difficult to cooperate in these studies. Patient 1 was unable to sit up, two patients could not be moved to the pulmonary function laboratory before treatment and only limited studies could be done. Vital capacity was within normal limits, while the residual volume and total lung capacity were increased in all patients. The ratio, residual volume/total lung capacity, was above 30 per cent in each patient but less than the expected value if age is considered (8). Other than the general condition of the patients, we have no adequate explanation for the increased residual volume. However, since neither significant airway obstruction nor uneven distribution of inspired gas was indicated by the other tests of pulmonary function, we can rule out any significant 
obstructive pulmonary disease. Further, since these patients gave no indication of significant pulmonary disease by history, or by physical or $\mathrm{X}$-ray examination, we inclined to the view that they were as free from pulmonary dysfunction as we could expect under the circumstances pertaining.

A summary of the measurements of the diffusing capacity of the lung at an alveolar $\mathrm{O}_{2}$ tension of about $100 \mathrm{~mm} \mathrm{Hg}$ in these patients, before and after blood replacement by transfusion, is given in Table II. More complete data are presented in Figure 1, which is a plot of $D_{L}$ for all five subjects, at varying alveolar $\mathrm{O}_{2}$ tension from 100 to about $600 \mathrm{~mm} \mathrm{Hg}$ before treatment. At the time of the first study, the average blood $\mathrm{Hb}$ concentration was $6 \mathrm{~g}$ per $100 \mathrm{ml}$, and after treatment the average blood $\mathrm{Hb}$ concentration was $11 \mathrm{~g}$ per 100 $\mathrm{ml}$. Each point in the figure is the average of two or more measurements of $D_{L}$. At all three levels of alveolar $\mathrm{O}_{2}$ tension, $\mathrm{D}_{\mathrm{L}}$ in the anemic state was lower than similar data from eight normal subjects at comparable alveolar $\mathrm{O}_{2}$ tensions (3) $(p<0.01)$. The value of $D_{L}$ (corrected to a standard alveolar $\mathrm{O}_{2}$ tension of $120 \mathrm{~mm} \mathrm{Hg}$ $\left.\left(D_{\mathbf{L}_{120}}\right)\right)$ for each patient was less than the value predicted from the body surface area (2) (p < $0.05)$. With the exception of the case of Patient 1 , each measured value of $D_{\mathbf{L}_{120}}$ was more than $2 \mathrm{SD}(8 \mathrm{ml}$ per minute per $\mathrm{mm} \mathrm{Hg}$ ) below the predicted value at the lower $\mathrm{Hb}$ concentration. Except for two data points of Patient 1, all of the $D_{L}$ measurements were less than the normal data even at the higher $\mathrm{Hb}$ concentration. At an av-

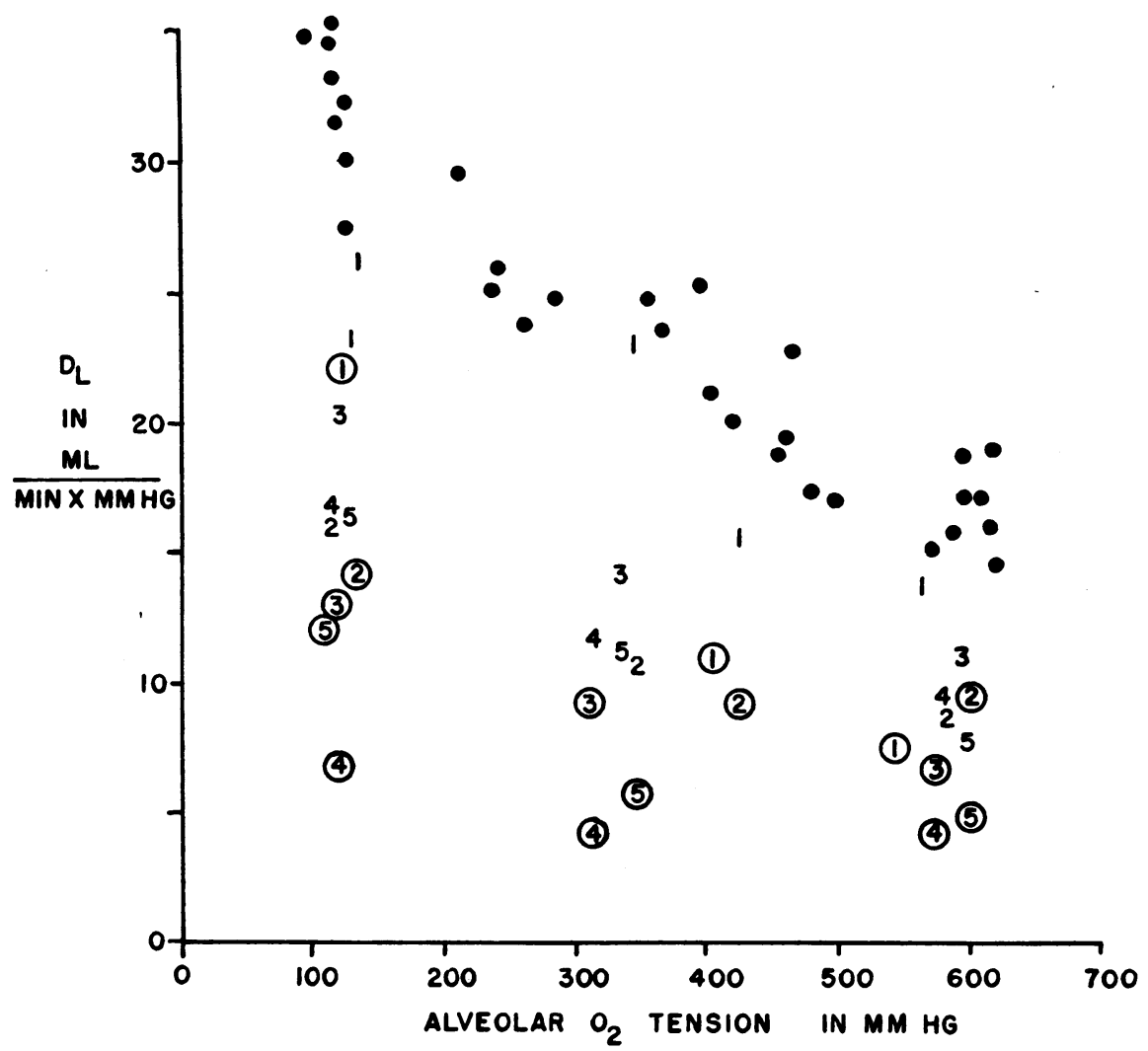

Fig. 1. The diffusing capacity of the Lung $\left(D_{L}\right)$ for each of the 5 patients PLOTTED AGAINST ALveOLAR $\mathrm{Po}_{2}$ IN MM HG. The circled figures indicate measurements made when the patients were severely anemic, prior to the therapy (average $\mathrm{Hb}$ conc. 6 $\mathrm{g}$ per $100 \mathrm{ml}$ ). The figures without circles indicate measurement made after therapy when the blood hemoglobin concentration had been raised (average $\mathrm{Hb}$ conc. $11 \mathrm{~g}$ per $100 \mathrm{ml}$ ). The numbers refer to the individual patients as in the tables. The solid circles (๑) are data from 8 normal subjects (3). Each point is the average of at least two observations. 
erage $\mathrm{Hb}$ concentration of $6.0 \mathrm{~g}$ per $100 \mathrm{ml}, \mathrm{D}_{\mathrm{L}_{120}}$ was 55 per cent of its predicted value.

In all five patients, after the increase in blood $\mathrm{Hb}$ concentration produced by transfusion, $\mathrm{D}_{\mathrm{L}_{120}}$ was increased (Table II, Figure 2). At an average $\mathrm{Hb}$ concentration of $11 \mathrm{~g}$ per $100 \mathrm{ml}, \mathrm{D}_{\mathrm{L}_{120}}$ was 77 per cent of its predicted value. The initial studies in Patient 1 were done with him supine, the later studies, sitting. Since $D_{L}$ is greater supine than sitting (2), this would tend to displace upward the most leftward point of the graph for Patient 1. Any correction applied for this fact would bring the data on this patient more into line with the remainder. On the average, a 10-day interval occurred between the pre- and post-transfusion studies in a given patient (range 3 to 16 days). Except at the highest alveolar tension in Patient 2, and in spite of variations between individuals, it can be seen (Figure 1) that $\mathrm{D}_{\mathrm{L}}$ was greater at the greater blood $\mathrm{Hb}$ concentration in all five patients, and at all three alveolar $\mathrm{O}_{2}$ tension levels. These differences are statistically significant.
Two major questions raised by the present results are: a) Why is $\mathrm{D}_{\mathrm{L}}$ less than the predicted normal value in all five patients? $b$ ) What is the mechanism of its increase after transfusion?

The five patients studied were of relatively small body size compared with the normal subjects whose data are given in Figure 1-an average surface area of $1.67 \mathrm{~m}^{2}$ as compared with an average of $2.00 \mathrm{~m}^{2}$. Under normal circumstances $D_{L}$ is less the smaller the body size (2) and this might be the explanation for the lower values of $D_{L}$ in Figure 1 and Table II. However, in four of five patients, the value of $D_{\mathbf{L}}$ (as measured at the lower hemoglobin concentration) was more than $2 \mathrm{SD}$ below the value predicted on the basis of body surface area. Only one patient had a $D_{L}$ outside these predicted limits after partial restoration of normal hemoglobin concentration. We conclude that the initial low values for $D_{L}$ are not entirely explicable on the basis of the small body size of the patients.

The effective surface area of the pulmonary membrane might have been reduced in these pa-

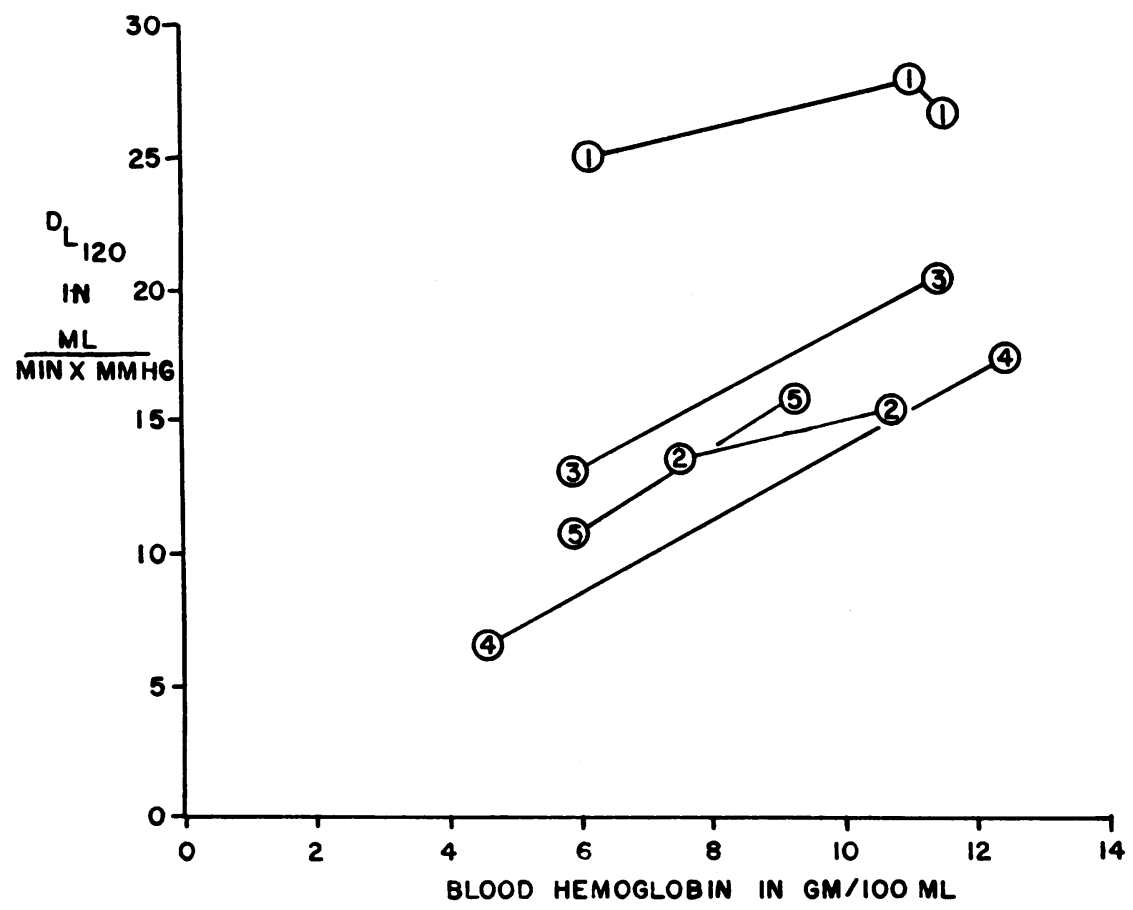

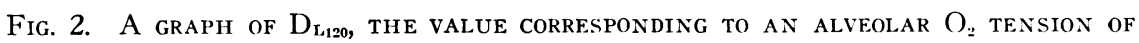
120 Mm Hg, against peripheral bloOd hemoglobin conCENTRATION FOR the 5 patifents studied. The numerals inside the circles indicate the patient from whom the datum derives. The lines connect measurements made at different levels of blood hemoglobin concentration on any single patient. 


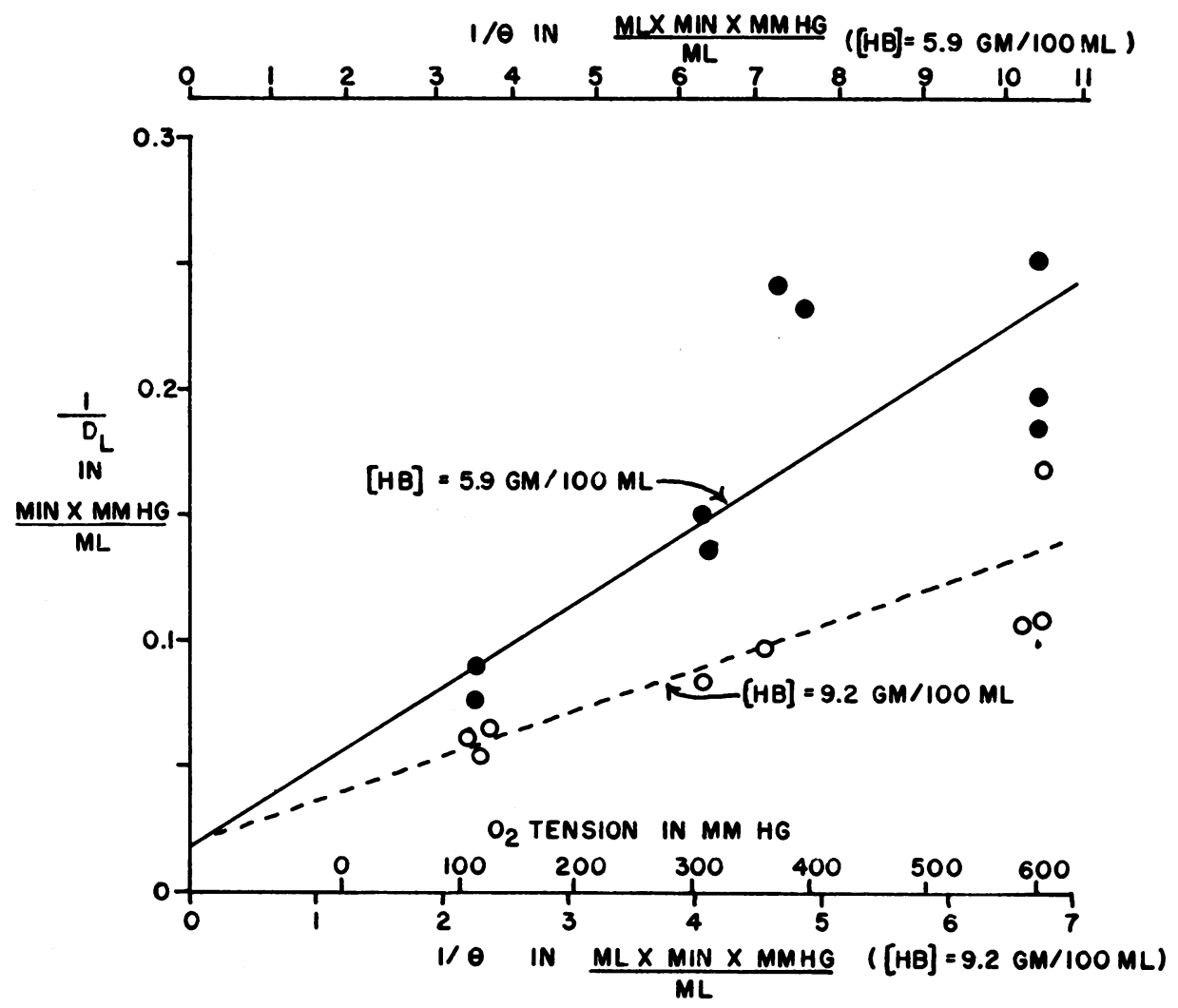

Fig. 3. A graph of $1 / D_{\mathrm{L}}$ Against $1 / \theta$ for Patient 5 , Before and after treatment of ANEMIA. Because $\theta$ is directly proportional to the blood $\mathrm{CO}$ capacity or hemoglobin concentration (1), the scales on the abscissae have to be different for the measurements before and after treatment of the anemia. The solid circles ( $)$ indicate measurements made when the patient's hemoglobin concentration was $5.9 \mathrm{~g}$ per $100 \mathrm{ml}$ and the abscissa should be read on the top scale. The open circles $(O)$ refer to measurements made after the patient had been transfused and the hemoglobin concentration in the blood had risen to $9.2 \mathrm{~g}$ per $100 \mathrm{ml}$. These data should be read on the lower scale. The approximate capillary $\mathrm{O}_{2}$ tension is also plotted on the abscissa and refers to either graph. The lines are the least mean squares regression lines for the two groups of data. The intercept on the ordinate equals $1 / \mathrm{D}_{M} ; \mathrm{D}_{M}$ is 45.5 and $50.0 \mathrm{ml}$ per minute per $\mathrm{mm} \mathrm{Hg}$ for the upper (more anemic) and lower (post-treatment) cases, respectively. The slopes of the two lines, calculated according to their particular abscissal scale, are proportional to $1 / \mathrm{V}_{\mathrm{c}}$. $\mathrm{V}_{\mathrm{c}}$ was 54.3 and 62.5 for the anemic and post-treatment measurements, respectively; each point is the mean of at least two observations.

tients by a chronic abnormality, such as pulmonary fibrosis, or a more acute process, such as pulmonary edema. However, save possibly in Patient 2 (who may have had some cardiopulmonary dysfunction following her transfusion reaction), there were no indications of abnormalities in the lungs by the usual clinical, radiological, or functional tests. Since, after transfusion, $\mathrm{D}_{\mathrm{L}_{120}}$ increased an average of 58 per cent in from 3 to 16 days, any abnormalities in the pulmonary membrane would have had to be rapidly reversible to explain the changes in $\mathrm{D}_{\mathrm{I}}$ found.
The values of the diffusing capacity of the pulmonary membrane and the pulmonary capillary blood volume presented in Table II were obtained from graphical solutions of Equation 1, by the data in Figure 1. This graphical solution for the case of Patient 5 is given in Figure 3. The initial measurements of $D_{L}$ were made when the patient's peripheral venous blood had a $\mathrm{Hb}$ concentration of $5.9 \mathrm{~g}$ per $100 \mathrm{ml}$. After transfusion this rose to $9.2 \mathrm{~g}$ per $100 \mathrm{ml}$ at the time of the second measurements of $\mathrm{D}_{\mathrm{L}} ; \theta$, the rate of combination of $\mathrm{CO}$ with the blood, is proportional to $\mathrm{Hb}$ 
concentration. Therefore, two scales are given on the abscissa, corresponding to the two blood $\mathrm{Hb}$ concentrations. The data were fitted to Equation 1 by the method of least squares. It should be noted that the two lines are plotted against different scales for $1 / \theta$ on the abscissa and that in actuality their slopes $\left(1 / \mathrm{V}_{\mathbf{c}}\right)$ are approximately equal.

A reduction in $D_{L}$ in anemia can be predicted from Equation 1 because of the increase in the intravascular diffusion resistance, $1 / \theta \mathrm{V}_{\mathrm{c}}$, secondary to the decrease in the rate at which $1 \mathrm{ml}$ of blood in the pulmonary capillaries can take up $\mathrm{CO}$ per $\mathrm{mm} \mathrm{Hg}$ of plasma $\mathrm{CO}$ tension. $\theta \mathrm{V}_{\mathrm{c}}$ could be considered the "diffusing capacity" of the red cells in the capillary bed at any instant.

If the only change in the pulmonary capillary bed in anemia were a decrease in the hematocrit of the pulmonary capillary blood, one would expect $D_{M}$ and $V_{c}$ (which are dependent mainly upon the dimensions of this bed) to be normal and remain relatively unchanged by therapy. Also one would expect the measured value of $\theta \mathrm{V}_{\mathrm{c}}$ in anemia to be less than normal and to rise with an increase in the hematocrit. As seen in Table II, $\mathrm{D}_{\mathbf{M}}$ was less than normal prior to therapy and increased after therapy in four of five patients, but these changes are not statistically significant. It should be remarked that $D_{\mathbf{M}}$ is obtained by extrapolation (see Figure 3 ) and that $1 / D_{M}$ lies near the origin except in severe pulmonary capillary block. Slight errors in the measured values of $\mathrm{D}_{\mathrm{L}}$ can lead to large proportional changes in $\mathrm{D}_{\mathbf{M}}$, making it theoretically a more variable measure than $V_{c}$. For example, the initial value of $D_{\mathbf{M}}$ in Patient 1 was infinity. In addition, unusually large variations in $D_{L}$ were found, particularly at high alveolar $\mathrm{O}_{2}$ tensions, because, when $D_{L}$ is reduced (as it was in these patients), the relative change in alveolar $\mathrm{CO}$ concentration during 10 seconds of breath-holding becomes small, and small analytical errors produce large changes in the calculated value of $D_{L}$. For example, in Patient 4 prior to treatment, the alveolar CO concentration fell between 10 and 25 per cent in 10 seconds. An analytical error of 3 per cent (which is not unrealistic) would produce an error in $\mathrm{D}_{\mathrm{L}}$ of between 14 and 30 per cent. $\mathrm{V}_{\mathrm{c}}$ tended to be closer to the predicted values than $\operatorname{did} \mathrm{D}_{\mathbf{M}}$, and rose in four of five patients, but again these changes are not statistically significant. It would not be unreasonable to expect an increase in the dimensions of the pulmonary capillary bed in anemia in view of the known increase in pulmonary blood flow seen in it (10).

$\theta \mathrm{V}_{\mathrm{c}}$, which actually equals the "diffusing capacity" of the red cells in the pulmonary capillary bed at any instant, was less than the predicted value and rose after therapy in all five patients; this change was statistically significant (p 0.03). Changes in $\theta \mathrm{V}_{\mathrm{c}}$ can be observed without having to make any assumptions as to the value of $\theta$, since $1 / \mathrm{D}_{\mathrm{L}}$ can be plotted against mean capillary $\mathrm{O}_{2}$ tension. These findings are in agreement with the hypothesis that in anemia $\mathrm{CO}$ movement within the pulmonary capillary blood is impeded. Since $\mathrm{V}_{\mathrm{e}}$, calculated on the basis of assumed changes in $\theta$, did not change significantly, it is most probable that $\theta \mathrm{V}_{\mathbf{c}}$ was reduced because $\theta$ was reduced, and the latter change could have been caused either because the number of red cells in the pulmonary capillary bed was reduced, or because the rate of CO uptake of the individual red cells was reduced. No data are available on the latter point, but there is no evidence to lead us to expect such an abnormality. If there had been an increase in the resistance to gas diffusion through the plasma of the pulmonary capillaries in the anemic state, this should have been interpreted as an increase in $D_{\mathbf{M}}$, because the "pulmonary membrane" includes the entire path between the surface of the red cells and the alveolar gas according to the analysis. It is not possible to obtain direct experimental measurements of the hemoglobin concentration in the pulmonary capillary blood, so we have assumed it is equal to that in the peripheral venous blood, and it is on this basis that the values of $\mathrm{V}_{c}$ in Table II have been calculated.

Since there appear no other reasonable explanations, it seems permissible to conclude that the initially reduced values of $D_{L}$ in these patients resulted from an increase in $1 / \theta \mathrm{V}_{c}$, and that the increase in $D_{\mathrm{L}}$, which occurred when the blood hematocrit rose, resulted from a decrease in this intravascular resistance.

Since the rate at which $1 \mathrm{ml}$ of normal whole blood takes up $\mathrm{O}_{2}$ from the plasma per $\mathrm{mm} \mathrm{Po}_{2}$ difference is of the same order as $\theta$ for CO (1), we presume that the rate of diffusion of $\mathrm{O}_{2}$ within the blood is also an important factor in determin- 
ing the rate of $\mathrm{O}_{2}$ exchange in the lungs as well as in the peripheral tissues. In anemia, where the total red cell surface available for $\mathrm{O}_{2}$ exchange in the capillaries at any instant is decreased, the $\mathrm{O}_{2}$ gradient would necessarily be increased.

Mochizuki and associates (11) have measured the diffusing capacity for $\mathrm{O}_{2}$ in anesthetized dogs, in which the red cell concentration was varied from about 2.5 to $6.8 \times 10^{9}$ per ml blood. They estimated the venous admixture percentage (arterialmixed venous) from $\mathrm{O}_{2}$ content and alveolar and arterial $\mathrm{Po}_{2}$ while the animal was breathing a gas mixture enriched with $\mathrm{O}_{2}$. These authors found that the calculated value of $\mathrm{D}_{\mathrm{L}}$ for $\mathrm{O}_{2}$ increased proportionally to the increase in hematocrit, other conditions remaining constant. This finding is consistent with the data in Figure 2.

\section{SUMMARY}

The diffusing capacity of the lung $\left(D_{L}\right)$ was measured by the breath-holding $\mathrm{CO}$ technique in five patients with severe chronic anemia, but without evidence of significant lung disease, before and after their blood hemoglobin concentration was increased by transfusion. Simple pulmonary function studies showed an increase in residual volume but no significant airway obstruction or non-uniform distribution of inspired gas.

$D_{\mathbf{L}}$ prior to therapy was less than predicted in all five patients. The average interval between the measurements of $D_{L}$ in each patient was 9 days, in which time $\mathrm{D}_{\mathrm{L}}$ at an average alveolar $\mathrm{O}_{2}$ tension of $120 \mathrm{~mm} \mathrm{Hg}$ had increased an average of 54 per cent; at an average alveolar $\mathrm{O}_{2}$ tension of $250 \mathrm{~mm} \mathrm{Hg}$ had increased an average of 95 per cent; and at an average alveolar $\mathrm{O}_{2}$ tension of 590 $\mathrm{mm} \mathrm{Hg}$ had increased an average of 69 per cent.

\section{ACKNOWLEDGMENTS}

The authors wish to thank Dr. Phyllis Marciano for invaluable technical assistance in performing these studies, the house staffs of the Philadelphia General Hospital and the Hospital of the University of Pennsylvania for their help in selecting the patients, and Dr. J. $\mathrm{H}$. Comroe, Jr., for much helpful criticism.

\section{REFERENCES}

1. Roughton, F. J. W., and Forster, R. E. Relative importance of diffusion and chemical reaction rates in determining the rate of exchange of gases in the human lung, with special reference to true diffusing capacity of pulmonary membrane and volume of blood in lung capillaries. J. appl. Physiol. 1957, 11, 290.

2. Ogilvie, C. M., Forster, R. E., Blakemore, W. S., and Morton, J. W. A standardized breath holding technique for the clinical measurement of the diffusing capacity of the lung for carbon monoxide. J. clin. Invest. 1957, 36, 1.

3. McNeill, R. S., Rankin, J., and Forster, R. E. The diffusing capacity of the pulmonary membrane and the pulmonary capillary blood volume in cardiopulmonary disease. Clin. Sci. 1958, 17, 465.

4. Forster, R. E., Fowler, W. S., Bates, D. V., and Van Lingen, B. Absorption of carbon monoxide by the lungs during breathholding. $J$. clin. Invest. 1954, 33, 1135.

5. Darling, R. C., Cournand, A., and Richards, D. W., Jr. Studies on intrapulmonary mixture of gases. III. An open circuit method for measuring residual air. J. clin. Invest. 1940, 19, 6091.

6. Cander, L., and Comroe, J. H., Jr. A method for the objective evaluation of bronchodilator drugs; effects of Dapanone, Isuprel, and aminophylline in patients with bronchial asthma. J. Allergy 1955, 26, 210.

7. Comroe, J. H., Jr., and Fowler, W. S. Lung function studies. VI. Detection of uneven alveolar ventilation during a single breath of oxygen. Amer. J. Med. 1951, 10, 408.

8. Greifenstein, F. E., King, R. M., Latch, S. S., and Comroe, J. H., Jr. Pulmonary function studies in healthy men and women 50 years and older. J. appl. Physiol. 1952, 4, 641.

9. Baldwin, E. de F., Cournand, A., and Richards, D. W., Jr. Pulmonary insufficiency: I. Physiological classifications, clinical methods of analysis, standard values in normal subjects. Medicine (Baltimore) 1948, 27, 243.

10. Ryan, J. M., and Hickam, J. B. The alveolar-arterial oxygen pressure gradient in anemia. J. clin. Invest. 1952, 31, 188.

11. Mochizuki, M., Anso, T., Goto, H., Hamamoto, A., and Makiguchi, $Y$. The dependency of the diffusing capacity on the $\mathrm{HbO}_{2}$ saturation of the capillary blood and on anemia. Jap. J. Physiol. 1958, 8, 225. 